\title{
Level Berpikir Geometri Peserta Didik Berdasarkan Teori Van Hiele pada Materi Bangun Ruang Sisi Datar
}

\author{
Anna Cesaria ${ }^{1,2 *}$, Tatang Herman ${ }^{1}$, Jarnawi Afgani Dahlan ${ }^{1}$ \\ ${ }^{1}$ Departemen Pendidikan Matematika, Universitas Pendidikan Indonesia \\ ${ }^{2}$ Program Studi Pendidikan Matematika, STKIP PGRI Sumatera Barat \\ *annacesaria13@gmail.com
}

\begin{abstract}
Abstrak
Berdasarkan Van Hiele dalam memahami geometri peserta didik perlu memahami lima Tahapan yaitu tahap 1 (tahap pengenalan), tahap 2 (tahap analisis), tahap 3 (tahap pengurutan), tahap 4 (tahap deduksi), dan tahap 5 (tahap ketepatan). Setiap peserta didik memiliki kemampuan berpikir geometri yang berbeda-beda. Penelitian ini bertujuan untuk mengkaji kemampuan geometri peserta didik SMP pada materi bangun ruang sisi datar menurut Teori Van Hiele. Penelitian ini termasuk dalam tipe penelitian kualitatif dengan desain studi kasus. Penelitian ini dilaksanakan pada tiga sekolah yang ada di Padang, Sumatera Barat, Indonesia. Subjek penelitian ini merupakan peserta didik SMP Negeri 1 Padang, SMP Negeri 7 Padang, dan SMP Negeri 25 Padang. Pengumpulan data dilaksanakan dengan memakai tes, wawancara dan dokumentasi. Analisis data dilaksanakan dengan tahap reduksi data, penyajian data, dan verifikasi data atau penarikan kesimpulan. Teknik originalitas data dilaksanakan dengan tenik trangulasi dimana peneliti memperbandingkan data hasil tes dengan hasil wawancara dengan peserta didik. Dari 94 peserta didik (Laki-laki $=38$, Perempuan 56) dilakukan tes berdasarkan level berpikir geometri Teori Van Hiele, diperoleh 92,55\% peserta didik mampu mencapai tahapan berpikir Van Hiele pada level visualisasi. Sebanyak 45,74\% peserta didik mampu mencapai level analisis geometri dan sebanyak 6,38\% peserta didik mencapai level abstraksi. Untuk level deduksi dan ketepatan peserta didik belum ada yang mampu menyelesaikan permasalahannya. Hasil yang diperoleh dalam penelitian ini yaitu kebanyakan peserta didik masih berada pada tahap 1 dan 2 . Tak seperti pendapat van Hiele yang mengungkapkan bahwa level berpikir geometri untuk peserta didik SMP berada di level 3. Menurut hasil penelitian, penting untuk melaksanakan pemerikasaan lebih lanjut mengenai level berpikir geometri peserta didik SMP di daerah lain.
\end{abstract}

Kata Kunci: bangun ruang sisi datar, kemampuan geometri, teori Van Hiele

\begin{abstract}
According to Van Hiele, in understanding geometry, students need to understand five stages, namely stage 1 (introduction stage), stage 2 (analysis stage), stage 3 (sequencing stage), stage 4 (deduction stage), and stage 5 (accuracy stage). Each student has different geometric thinking abilities. This study aims to examine the geometric abilities of junior high school students in the material of flat-sided geometry according to Van Hiele's Theory. This research belongs to the type of qualitative research with a case study design. It was conducted at three schools in Padang, West Sumatra, Indonesia. The subjects were students of SMP Negeri 1 Padang, SMP Negeri 7 Padang, and SMP Negeri 25 Padang. Data collection was carried out using tests, interviews, and documentation. Data analysis was carried out with the stages of data reduction, data presentation, and data verification or drawing conclusions. The data originality technique was carried out with the triangulation technique, where the researcher compared the test data with the results of interviews with students. Of the 94 students (male $=38$, female 56) tested based on the geometric thinking level of Van Hiele
\end{abstract}


Theory, $92.55 \%$ of the students reached the Van Hiele thinking stage at the visualization level. As many as $45.74 \%$ of students reached the level of geometric analysis, and $6.38 \%$ of students reached the level of abstraction. For the level of deduction and accuracy, no one has been able to solve the problem. The results obtained in this study are that most students are still at stages 1 and 2, unlike van Hiele's opinion, which revealed that the level of geometric thinking for junior high school students is at level 3. According to the study results, it is essential to carry out further checks on the level of geometric thinking of junior high school students in other areas.

Keywords: polyhedral, students' geometry ability, Van Hiele's theory

Received: December 10, 2020 / Accepted: February 22, 2021 / Published Online: July 13, 2021

\section{Pendahuluan}

Geometri adalah salah satu diantara cabang pembelajaran matematika. Geometri sangat erat kaitannya dengan permasalaham dalam kehidupan sehari-hari, sebab pada sebenarnya segala visualisasi yang ada di muka bumi ini adalah sebuah geometri. Geometri menyentuh setiap aspek dari kehidupan (Mamolo \& Ruttenberg, 2015). Dengan mempelajari geometri peserta didik akan terlatih berpikir logis dan akan mempertajam intuisi spasialnya yang dapat peserta didik gunakan dalam kehidupan sehari-hari (Clements, 2003). Salah satu pokok bahasan geometri adalah bangun ruang sisi datar. Sepatutnya lebih mudah untuk memahami materi ini, sebab bangun ruang telah mereka peroleh saat berada di jenjang sekolah dasar seperti bangun ruang kubus, balok, dan prisma. Hanya saja bangun ruang untuk jenjang tingkat menengah pertama menambahkan bangun ruang limas. Geometri menempati posisi khusus dalam kurikulum matematika menengah, sebab banyaknya konsep-konsep yang termuat di dalamnya.

Berdasarkan sudut pandang guru, geometri dianggap masih sulit untuk diajarkan. Salah satu masalah utama adalah kesulitan guru dalam memberikan pembelajaran geometri, itu disebabkan karena kurangnya media pembelajaran (Sariyasa, 2017). Selain itu, dalam menanamkan konsep dalam geometri, guru memilih metode mengajar dengan cara dihafal. Guru matematika lebih menekankan pada aspek geometri memori (Ramlan, 2016). Peserta didik secara langsung dijelaskan mengenai konsep geometri di papan tulis atau pun menggunakan alat peraga, tetapi peserta didik tidak ikut berpartisipasi aktif dalam proses pembelajaran. Selain itu, peserta didik pun dikenalkan rumus-rumus yang terkait dengan bangun ruang secara langsung tanpa peserta didik memahaminya secara mendalam. Hal ini terjadi pada beberapa penelitian bahwa peserta didik melakukan kesalahan dalam menyelesaikan persoalan geometri disebabkan oleh rendahnya pengusaan konsep geometri dan 
rendahnya analisis terhadap unsur-unsur geometri yang berkaitan dengan penyelesaian masalah dalam kehidupan sehari-hari (Özerem, 2012). Maka dari itu, dalam proses pembelajaran geometri secara tepat harus diperhatikan level berpikir geometri pada setiap tingkatan kemampuan matematika peserta didik serta pemilihan rancangan pembelajaran yang tepat.

Pada materi geometri khususnya bangun ruang sisi datar ditemukan kendala ontogenical dan epistemologis dalam proses pembelajaran geometri (Cesaria \& Herman, 2019). Kendala ontogenical terjadi pada peserta didik yang tidak memiliki pemahaman yang memadai terhadap materi yang diberikan serta kendala epistemologis terjadi ketika bahan ajar yang diberikan tidak sesuai karakteristik individu peserta didik. Kendala pada peserta didik yang tidak memiliki pemahaman berdampak lemahnya kemampuan peserta didik dalam berpikir geometri. Pada pembelajaran geometri perlu memperhatikan tahap-tahap berpikir peserta didik (Abdussakir, 2009). Hal ini sejalan dengan teori Van Hiele yang mengungkapkan bahwa pembelajaran matematika khususnya geometri harus sesuai dengan level perkembangan kemampuan berpikir geometri peserta didik. Beberapa penelitian yang telah dilakukan membuktikan dampak yang positif dalam pembelajaran geometri Van Hiele memfokuskan teorinya dalam bidang geometri (Burais \& Husna, 2018). Menurut teori Van Hiele menyatakan bahwa kualitas pengetahuan peserta didik tidak hanya ditentukan oleh akumulasi pengetahuannya, namun lebih ditentukan dari cara proses berpikir yang digunakan masing-masing peserta didik (Mason, 2009).

Van Hiele mengungkapkan tahapan berpikir peserta didik dalam memahami geometri yaitu melalui tahap pengenalan, tahap analisis, tahap pengurutan, tahap deduksi, dan tahap ketepatan (Vojkuvkova, 2012) (Lestariyani, Ratu, \& Yunianta, 2014). Setiap level berpikir geometri mendeskripsikan proses berpikir peserta didik dalam konteks geometri. Level berpikir geometri menjelaskan bagaimana peserta didik berpikir dan ide geometri apa yang peserta didik pikirkan, dibandingkan berapa banyak pengetahuan yang mereka miliki (Nopriana, 2014). Van Hiele berkeyakinan bahwa tingkatan yang lebih tinggi diperoleh tidak dengan metode ceramah, tetapi melalui pemilihan latihan-latihan yang tepat (Abu \& Abidin, 2013). Lebih lanjut Mayberry mengatakan bahwa murid yang berada pada suatu tingkat dapat menjawab semua pertanyaan tingkat berikutnya (Burger, Shaughnessy, Education, \& Jan, 1986). Peserta didik harus melewati suatu level secara berurutan secara matang sebelum menuju level berikutnya (Haviger \& Vojkůvková, 2015). Level berpikir geometri dilalui peserta didik secara berurutan. Peserta didik harus melewati suatu level dengan matang sebelum menuju level berikutnya. 
Peserta didik yang didukung dengan pengalaman pengajaran yang tepat, akan melewati lima level berpikir geometri tersebut, dimana peserta didik tidak dapat mencapai satu level tanpa melewati level sebelumnya (Salifu, Yakubu, \& Ibrahim, 2018). Setiap level menunjukkan kemampuan berpikir yang digunakan seseorang dalam belajar konsep geometri. Kecepatan berpindahnya suatu level ke level berikutnya lebih banyak bergantung pada isi, metode dan media pembelajaran dari pada umur dan kematangan peserta didik.

Level 1 (visualisasi), pada level ini siswa mengenal bentuk-bentuk geometri hanya sekedar karakteristik visual dari suatu objek. Peserta didik yang memandang objek secara keseluruhan namun tidak terfokus pada sifat-sifat objek yang diamati. Oleh karena itu, pada level ini peserta didik tidak dapat memahami dan menentukan sifat geometri dan karakteristik bangun yang ditunjukkan (Khoiri, 2014). Level 2 (analisis), pada level ini sudah terlihat adanya analisis peserta didik terhadap konsep dan sifat-sifat bangun geometri. Peserta didik dapat menentukan sifat-sifat suatu bangun dengan melakukan pengamatan, pengukuran, menggambar dan membuat model. Meskipun demikian, peserta didik belum sepenuhnya dapat menjelaskan hubungan antara sifat-sifat tersebut, belum dapat melihat hubungan antara beberapa bangun geometri dan mereka belum mampu memahami definisi (Ma, Lee, \& Lin, 2015).

Level 3 (abstraksi), pada level ini peserta didik sudah dapat melihat hubungan sifat-sifat pada suatu bangun geometri dan sifat-sifat dari berbagai bangun dengan menggunakan abstraksi dan dapat mengklasifikasikan bangun-bangun secara hierarki. Peserta didik pada level berpikir ini sudah dapat melihat hubungan sifat-sifat pada suatu bangun (Yudianto, E., Sugiarti, T., \& Trapsilasiwi, 2018). Level 4 (deduksi), pada level ini peserta didik tidak hanya sekedar menerima bukti, tetapi sudah mampu menyusun bukti. Siswa mampu membuat sebuah daftar aksioma dan definisi untuk membuat teorema. Peserta didik juga membuktikan teorema tersebut dengan menggunakan pemikiran logis, dibandingkan pemikiran pada level 3 yang lebih cenderung informal (Hock, Tarmizi, Yunus, \& Ayub, 2015). Level 5 (ketepatan), pada level ini peserta didik bernalar secara formal dalam sistem matematika dan dapat menganalisis konsekuensi dari manipulasi aksioma dan definisi. Saling keterkaitan antara bentuk yang tidak didefinisikan, aksioma, definisi, teorema dan pembuktian formal dapat dipahami. Pada level ini memerlukan tahap berpikir yang kompleks dan rumit, oleh karena itu level ini jarang dicapai oleh peserta didik sekolah menengah atas (Fitriyani, Widodo, \& Hendroanto, 2018). Pada penelitian terdahulu belum ada yang melakukan analisis level berpikir geometri untuk materi 
bangun ruang sisi datar, maka dari itu peneliti melakukan analisis level berpikir geometri khususnya materi bangun ruang sisi datar. Berdasarkan paparan di atas, maka perlu dilakukan penelitian untuk mengetahui level berpikir geometri peserta didik berdasarkan teori Van Hiele pada materi bangun ruang sisi datar.

\section{Metode}

Dalam penelitian ini mengambil lokasi penelitian di tiga SMP yang ada di Padang, Sumatera Barat, Indonesia dengan klasifikasi kemampuan peserta didik tinggi, sedang, dan rendah adalah SMP Negeri 1 Padang, SMP Negeri 7 Padang, dan SMP Negeri 25 Padang. Metode penelitian yang digunakan yaitu metode penelitian kualitatif dengan jenis penelitian studi kasus karena tujuan penelitian ini menganalisis level berpikir geometri peserta didik dalam menyelesaikan soal-soal bangun ruang sisi datar berdasarkan Teori Van Hiele (Creswell, 2012). Sumber data dalam penelitian ini didapatkan dari hasil tes dan wawancara kepada 94 peserta didik masing-masing satu kelas setiap sekolah dengan cara pengambilan sample purposive sampling. Instrumen yang digunakan yaitu tes tertulis dan wawancara dengan indikator level berpikir geometri Teori Van Hiele. Pemberian tes tertulis berupa soal-soal bangun ruang sisi datar menurut teori Van Hiele dengan 6 butir soal yang telah divalidasi oleh dua orang ahli bidang geometri. Dari hasil validasi didapatkan hasil bahwa soal-soal pada tes tertulis sudah berada pada level berpikir geometri berdasarkan indikator Teori Van Hiele (Tabel 1). Untuk wawancara dilakukan kepada peserta didik yang mengisi lembar jawaban untuk memverifikasi data yang berguna untuk penarikan kesimpulan. Data yang dihasilkan yaitu data deskriptif yang berupa kata-kata tertulis atau lisan. Analisa data dilaksanakan dengan tahap reduksi data, penyajian data, dan verifikasi data atau penarikan kesimpulan. Teknik keabsahan data dilaksanakan dengan tenik triangulasi dimana peneliti membandingkan data hasil tes dengan hasil wawancara dengan peserta didik.

Tabel 1. Indikator Level Berpikir Geometri Teori Van Hiele

\begin{tabular}{|c|c|c|}
\hline No. & Level & Indikator \\
\hline 1 & Visualisasi & $\begin{array}{l}\text { 1. membuat bangun dengan mengkonstruk bangun } \\
\text { 2. mengidentifikasi bangun berdasarkan penampakkannya }\end{array}$ \\
\hline 2 & Analisis & $\begin{array}{l}\text { 1. mendeskripsikan suatu bangun sesuai sifat-sifatnya } \\
\text { 2. membandingkan bangun-bangun berdasarkan karakteristik } \\
\text { sifat-sifatnya }\end{array}$ \\
\hline 3 & Abstraksi & $\begin{array}{l}\text { 1. menggunakan model atau gambar sebagai sarana untuk } \\
\text { berpikir dan mulai mencari generalisasi atau contoh kontra } \\
\text { 2. menyajikan argumen informal }\end{array}$ \\
\hline
\end{tabular}




\section{Hasil Penelitian}

Dari hasil penelitian diberikan soal tes sebanyak 6 butir soal dengan level berpikir geometri Teori Van Hiele. Berikut merupakan contoh jawaban peserta didik yang saat dihadapkan pada soal - soal bangun ruang sisi datar berdasarkan Teori Van Hiele.

\section{Level Visualisasi (Pengenalan)}

Level visualisasi tahap Van Hiele dapat diidentifikasi dari proses penyelesaian peserta didik dalam menjawab soal nomor 1 dan 2 yang diberikan peneliti.

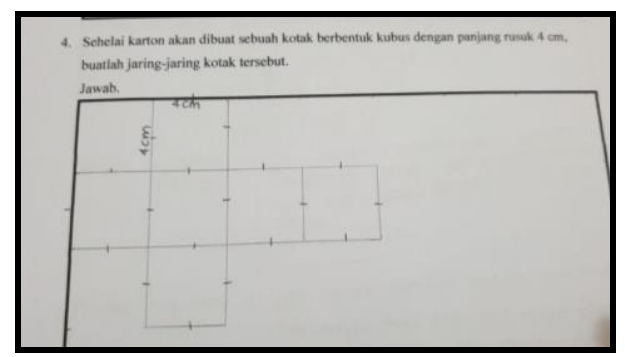

Gambar 1. Jawaban Peserta Didik pada soal level Visualisasi

Berdasarkan jawaban peserta didik dari gambar 1 tampak bahwa peserta didik dapat memahami maksud soal yang memuat indikator dari level Visualisasi. Peserta didik dalam level ini mampu memaknai maksud yang ditanyakan pada soal yaitu untuk membuat kubus dengan panjang rusuk $4 \mathrm{~cm}$ dengan membuat jaring-jaring kubus. Pada dasarnya peserta didik memahami dan mampu menunjukkan jaring-jaring kubus. Hal demikian pun diperkuat oleh hasil wawancara yang menggambarkan bahwa peserta didik mampu menunjukan jaring-jaring sehingga terbentuknya bangun ruang kubus tersebut. Terdapat jawaban peserta didik yang menggambarkan jaring-jaring kubus hanya dengan sketsa yang tertuliskan ukuran $4 \mathrm{~cm}$. Berdasarkan hasil tes yang diperoleh dari beberapa peserta didik tersebut dan diperkuat dari hasil wawancara peneliti dengan peserta didik, maka dapat disimpulkan bahwa secara umum peserta didik menengah pertama mampu mengerjakan soal-soal bangun ruang sisi datar berdasarkan Teori Van Hiele dan mencapai level visualisasi.

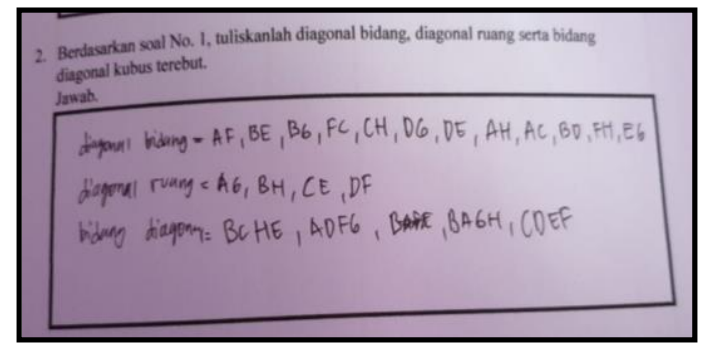

Gambar 2. Jawaban Peserta Didik pada soal level Visualisasi 
Berdasarkan jawaban peserta didik dari gambar 2 kelihatan bahwa peserta didik dapat memahami maksud soal yang memuat indikator dari tahapan visualisasi. Peserta didik dalam level ini mampu menuliskan diagonal bidang, diagonal ruang dan bidang diagonal dengan benar. Saat dilakukan wawancara dengan peneliti, peserta didik mampu menunjukkan diagonal bidang dan diagonal ruang namun tidak mampu menyebutkan definisinya. Hal ini berarti peserta didik mampu mencapai level visualisasi. Berdasarkan hasil tes yang diperoleh dari beberapa peserta didik tersebut dan diperkuat dari hasil wawancara peneliti dengan peserta didik, maka dapat disimpulkan bahwa secara umum peserta didik menengah pertama mampu mengerjakan soal-soal bangun ruang sisi datar berdasarkan teori Van Hiele dan mencapai level visualisasi.

\section{Level Analisis}

Level analisis tahap Van Hiele dapat diidentifikasi dari proses penyelesaian peserta didik dalam menjawab soal nomor 3 dan 4 yang diberikan peneliti.

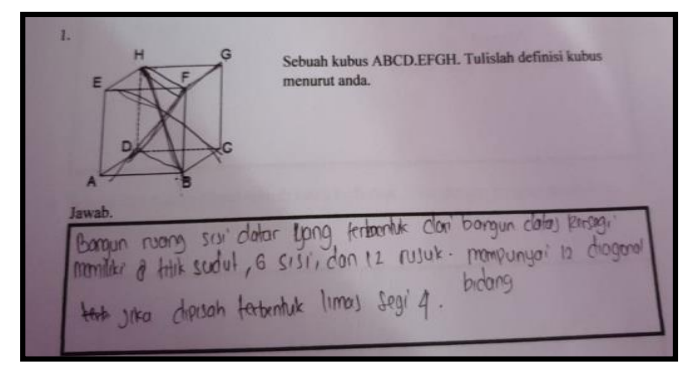

Gambar 3. Jawaban Peserta Didik pada soal level Analisis

Menurut jawaban peserta didik dari gambar 3 terlihat bahwa peserta didik bisa memahami maksud soal yang memuat indikator dari level analisis. Peserta didik dalam level ini mampu mendefinisikan sebuah kubus yang disajikan dengan menyebutkan unsur-unsur pada kubus yaitu memiliki 6 sisi, 12 rusuk, 8 titik sudut, 12 diagonal bidang, dan mampu menuliskan bahwa jika kubus tersebut dipisahkan maka akan membentuk limas segi empat walaupun tidak menyebutkan secara lengkap mengenai jumlah limas segi empat yang dibentuk. Hal ini berarti dapat dikatakan bahwa peserta didik mampu mencapai level analisis. Untuk soal selanjutnya masih pada level analisis. 


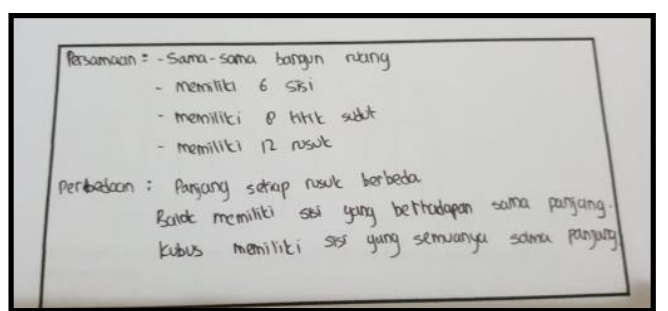

Gambar 4. Jawaban Peserta Didik pada soal level Analisis

Berdasarkan jawaban peserta didik dari gambar 4 tampak bahwa peserta didik dapat memahami maksud soal yang memuat indikator dari level analisis. Peserta didik dalam level ini mampu membedakan dan membandingkan antara dua bangun ruang yaitu kubus dan balok. Kebanyakan peserta didik sudah dapat menjawab persamaan beserta perbedaan kubus dan balok berdasarkan unsur-unsurnya. Persamaan kubus dan balok yang peserta didik jelaskan yaitu sama-sama bangun ruang dan memiliki 6 sisi, 12 rusuk, 8 titik sudut. Sedangkan untuk perbedaan antara kedua bangun ruang tersebut mereka menuliskan bahwa pada bangun ruang balok memiliki panjang rusuk yang berbeda dan setiap sisi yang berhadapan sama panjang, lain hal dengan kubus yaitu memiliki sisi yang sama. Berdasarkan wawancara yang dilakukan peneliti pun peserta didik mampu menemukan unsur dan sifat dari kedua bangun ruang tersebut. Hal ini berarti dapat dikatakan bahwa peserta didik mampu mencapai level analisis.

\section{Level Abstraksi (Pengurutan)}

Level abstraksi tahap Van Hiele dapat diidentifikasi dari proses penyelesaian peserta didik dalam menjawab soal nomor 5 dan 6 yang diberikan peneliti.

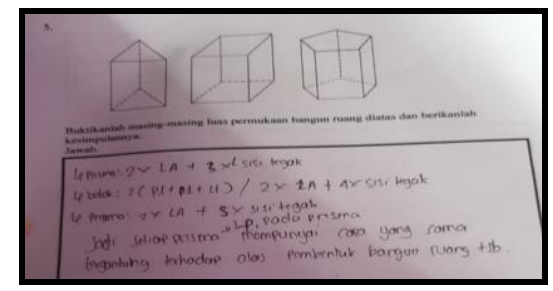

Gambar 5. Jawaban Peserta Didik pada soal level abstraksi

Berdasarkan jawaban peserta didik dari gambar 5 tampak bahwa peserta didik tidak dapat memahami maksud soal yang memuat indikator dari level abstraksi. Semua peserta didik dalam level ini belum mampu menemukan konsep luas permukaan prisma segitiga, prisma segiempat, dan prisma segilima, sehingga peserta didik tidak dapat menemukan kesimpulan dari keterkaitan jawaban yang diperoleh. Peserta didik hanya mampu menuliskan bahwa untuk 
memperoleh luas permukaan tersebut yaitu luas alas ditambahkan dengan luas sisi tegak namun tidak dipaparkan secara mendalam rumus luas tersebut dan hanya dapat menyimpulkan bahwa luas pemukaan prisma bergantung pada alas yang membentuk bangun ruang tersebut. Saat dilakukan wawancara dengan peneliti, pada umumnya peserta didik mengetahui dan memahami jaring-jaring bangun ruang, namun jika dikaitkan pada luas permukaan bangun ruang, mereka belum memahami. Padahal untuk menemukan konsep luas permukaan bangun ruang diperoleh menggunakan berbantuan jaring-jaring tersebut sehingga mendapatkan rumus luas permukaan prisma secara umum.

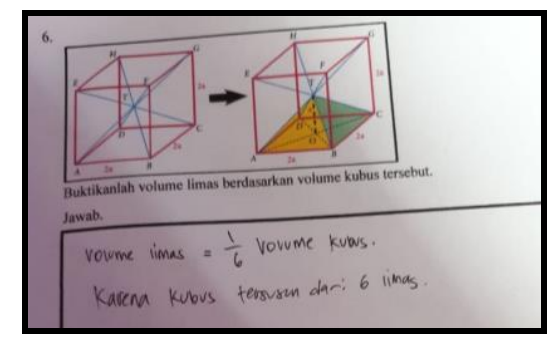

Gambar 6. Jawaban Peserta Didik pada soal level abstraksi

Berdasarkan jawaban peserta didik dari gambar 6 tampak bahwa umumnya peserta didik tidak dapat memahami maksud soal yang memuat indikator dari level abstraksi. Semua peserta didik dalam level ini belum mampu membuktikan volume limas secara umum berdasarkan kubus yang telah disajikan dalam soal. Peserta didik belum mampu mengaitkan antara bangun ruang ruang limas dan kubus, sehingga peserta didik sulit menemukan konsep volume limas tersebut. Peserta didik hanya menuliskan jawaban bahwa volume limas didapatkan dari kubus yang dibagi menjadi 6 . Tidak adanya penjelasan yang mengarahkan pada jawaban yang benar. Peserta didik saat dilakukan wawancara dengan peneliti, pada umumnya peserta didik mengetahui bahwa kubus tersebut dibentuk dari limas segiempat, namun peserta didik masih kesulitan dalam membuktikan rumus volume dan belum mampu mendefiniskan volume bangun ruang. Berdasarkan hasil tes yang diperoleh dan diperkuat dengan hasil wawancara dari beberapa peserta didik tersebut, maka dapat disimpulkan bahwa semua peserta didik belum mampu mengerjakan soal-soal bangun ruang sisi datar level abstraksi berdasarkan teori Van Hiele.

Dari hasil tes dan wawancara yang dilaksanakan peneliti seputar kemampuan geometri peserta didik sekolah menengah pertama dalam memecahkan soal-soal bangun ruang sisi datar menurut Teori Van Hiele. Secara keseluruhan, dari 94 orang peserta didik SMP Negeri 1 Padang, SMP Negeri 7 Padang dan SMP Negeri 25 Padang yang telah dilakukan tes 
berdasarkan level berpikir geometri Teori Van Hiele diperoleh 92,55\% peserta didik mencapai level visualisasi. Peserta didik sebanyak $45,74 \%$ mencapai level berpikir geometri analisis dan 6,38\% peserta didik mencapai level berpikir geometri abstraksi. Untuk level berpikir geometri deduksi dan ketepatan peserta didik belum ada yang mampu menyelesaikannya permasalahannya.

\section{Pembahasan}

Berdasarkan indikator level berpikir geometri teori Van Hiele yang diberikan kepada peserta didik, pada soal level visualisasi terdapat indikator membuat bangun dengan mengkonstruk bangun dan mengidentifikasi bangun berdasarkan penampakkannya. Pada level analisis terdapat indikator mendeskripsikan suatu bangun sesuai sifat-sifatnya dan membandingkan bangun-bangun berdasarkan karakteristik sifat-sifatnya. Pada level abstraksi terdapat indikator menggunakan model atau gambar sebagai sarana untuk berpikir dan mulai mencari generalisasi atau contoh kontra dan menyajikan argument informal. Untuk level 1 (visualisasi) peserta didik pada umumnya sudah mencapai maksimal dalam kedua indikator. Untuk level 2 (analisis) indikator pertama peserta didik telah mampu menyelesaikkanya sedangkan untuk indikator kedua peserta didik masih sedikit yang memahami perbedaan dua bangun ruang berdasarkan sifat-sifatnya. Untuk level 3 (abstraksi) pada umumnya peserta didik belum mampu untuk menyelesaikannya. Dari indikator-indikator level berpikir geometri Teori Van Hiele tersebut terlihat bahwa peserta didik Sekolah Menengah Pertama (SMP) di Kota Padang untuk level 1(visualisasi) dan level 2 (analisis) sudah mampu menyelesaikannya, tetapi untuk level 3 (abstraksi) masih belum mencapai maksimal.

Dari hasil analisis terhadap kemampuan geometri peserta didik berdasarkan teori Van Hiele menunjukkan bahwa secara umum peserta didik sekolah menengah pertama berada pada tahap 1 dan tahap 2. Tentu hal ini belum sesuai dengan Van De Wall yang menunjubanyakkkan bahwa peserta didik sekolah menengah pertama diharapkan sudah menempati pada tahap 3 dalam berpikir geometri, karena akan menjadi prasyarat untuk memasuki sekolah menengah atas (Muhassanah, Sujadi, \& Riyadi, 2014). Peserta didik dalam jenjang menengah pertama diharapkan telah mencapai level tiga dalam berpikir geometri. Hal ini dikarenakan hasil dari beberapa penelitian yang melaporkan bahwa jika peserta didik tidak mencapai level 3 berpikir geometri di SMP, maka peserta didik akan kesulitan dalam pembelajaran geometri di SMA (Usiskin, 1982) (Usman, Yew, \& Saleh, 2019). Permasalahan pada kemampuan berpikir 
geometri yang rendah terkait dengan teori Van Hiele level 2 (analisis) dan level 3 (abstraksi) tidak mencapai potensi sepenuhnya (Ramlan, 2016). Level berpikir geometri pada kelas menengah, peserta didik baru sampai level 1 (visualisasi) dan level 2 (analisis) sedangkan level 3 (abstraksi) peserta didik belum ada yang mampu mencapai level tersebut (Abu \& Abidin, 2013). Dalam proses pembelajaran sebagian peserta didik masih lemah dalam kemampuan berpikir geometri dalam visualisasi, analisis, dan abstraksi (Budiman, 2018).

Beberapa penelitian pun menyatakan analisis silabus dan buku tidak ada peserta didik SMP yang berada pada level 4 dan 5, maka dari itu berdasarkan level berpikir geometri peserta didik SMP diadopsi descriptor level berpikir Van Hiele untuk 3 tingkatan saja, yatu visualisasi, analisis dan abstraksi (Sulistiowati, Herman, \& Jupri, 2019). Peserta didik akan mengalami hambatan dan menemukan kesulitan dalam menerima materi geomteri jika belum berada pada tahap berpikir geometri 3 tingkatan sebelumnya.

\section{Simpulan}

Secara keseluruhan peserta didik sekolah menengah pertama pada materi bangun ruang sisi datar hanya mampu berada pada tahap 1 dan 2 dalam berpikir geometri berdasarkan teori van Hiele. Setelah mengetahui deskripsi level berpikir geometri peserta didik, maka hasil penelitian ini dapat dijadikan bahan referensi bagi guru dalam menentukan cara mengajar yang tepat dan efektif sesuai dengan level berpikir geometri Teori Van Hiele. Dengan ini maka perlu adanya peran guru untuk merancang pembelajaran geometri dengan memperhatikan level berpikir geometri peserta didik menengah pertama, karena pada idealnya peserta didik sekolah menengah pertama harus berada di level 3 berpikir geometri untuk prasyarat memasuki tahap 4 dan 5 di sekolah menengah atas. Peneliti selanjutnya perlu mengkaji lebih dalam lagi mengenai faktor-faktor yang menyebabkan peserta didik sekolah menengah pertama ini masih berada pada tahap 1 dan 2 level berpikir geometri. Kemudian menemukan metode pembelajaran yang tepat untuk meningkatkan tahap berpikir geometri peserta didik.

\section{Referensi}

Abdussakir, A. (2009). Pembelajaran geometri sesuai teori Van Hiele. (April 2012). https://doi.org/10.18860/jt.v2i1.1832.

Abu, M. S., \& Abidin, Z. Z. (2013). Improving the levels of geometric thinking of secondary school students using geometry learning video based on Van Hiele theory. International Journal of Evaluation and Research in Education (IJERE), 2(1), 16-22. https://doi.org/10.11591/ijere.v2i2.1935.

Budiman, H. (2015). Analisis kemampuan berpikir geometri mahasiswa pendidikan 
matematika. Jurnal Prisma, 4(8), 28-40.

Burais, F. F., \& Husna. (2018). Peningkatan kemampuan pemecahan masalah geometri melalui pembelajaran kooperatif berbasis teori Van Hiele. Jurnal Peluang, 6(2), 52-57. https://doi.org/10.36294/jmp.v2i2.208.

Burger, W. F., Shaughnessy, J. M., Education, M., \& Jan, N. (1986). Characterizing the Van Hiele levels of development in geometry. Journal for Research in Mathematics Education, 17(1), 31-48. https://doi.org/10.2307/749317.

Cesaria, A., \& Herman, T. (2019). Learning obstacle in geometry. Journal of Engineering Science and Technology, 14(3), 1271-1280.

Clements, D. H. (2003). Teaching and learning geometry. State University of New York at Buffalo.

Creswell, J. W. (2012). Educational research: Planing, conducting and evaluating quantitative research (4th editio). Boston, MA: Pearson Education, Inc.

Fitriyani, H., Widodo, S. A., \& Hendroanto, A. (2018). Students' geometric thinking based on Van Hiele's theory. Journal of Mathematics Education, 7(1), 55-60. https://doi.org/10.22460/infinity.v7i1.p55-60.

Haviger, J., \& Vojkůvková, I. (2015). The Van Hiele levels at Czech secondary schools. Procedia-Social and Behavioral Sciences, 171, 912-918. https://doi.org/10.1016/j.sbspro.2015.01.209.

Hock, T. T., Tarmizi, R. A., Yunus, A. S., \& Ayub, A. F. (2015). Understanding the primary school students' Van Hiele levels of geometry thinking in learning shapes and spaces : A Q-methodology. 11(4), 793-802. https://doi.org/10.12973/eurasia.2015.1439a.

Khoiri, M. (2014). Pemahaman siswa pada konsep segiempat berdasarkan teori Van Hiele. (November), 262-267.

Lestariyani, S., Ratu, N., \& Yunianta, T. N. H. (2014). Identifikasi tahap berpikir geometri siswa SMP Negeri 2 Ambarawa berdasarkan teori Van Hiele. Satya Widya, 30(2), 96-103. https://doi.org/10.24246/j.sw.2014.v30.i2.p96-103.

Ma, H., Lee, D., \& Lin, S. (2015). A study of Van Hiele of geometric thinking among 1 st through 6 th graders. 11(168), 1181-1196. https://doi.org/10.12973/eurasia.2015.1412a.

Mamolo, A., \& Ruttenberg, R. (2015). Developing a network of and for geometric reasoning. ZDM, (April 2016). https://doi.org/10.1007/s11858-014-0654-3.

Mason, M. (2009). The Van Hiele levels of geometric understanding. Colección Digital Eudoxus, 1(2).

Muhassanah, N., Sujadi, I., \& Riyadi. (2014). Analisis keterampilan geometri siswa dalam memecahkan masalah geometri berdasarkan tingkat berpikir Van Hiele. Jurnal Elektronik Pembelajaran Matematika, 2(1), 54-66.

Nopriana, T. (2014). Berpikir geometri melalui model pembelajaran geometri Van Hiele. Delta, 2(1), 41-50.

Özerem, A. (2012). Misconceptions in geometry and suggested solutions for seventh grade students. Procedia - Social and Behavioral Sciences, 55, 720-729. https://doi.org/10.1016/j.sbspro.2012.09.557.

Ramlan, A. M. (2016). The effect of Van Hiele learning model toward geometric reasoning ability based on self-efficacy of senior high school students. Journal of Mathematics Education, 1(2), 62-71.

Salifu, A. S., Yakubu, A.-R., \& Ibrahim, F. I. (2018). Van Hiele geometric thinking levels of pre-service teachers' of E.P. college of education, Bimbilla-Ghana. Journal of Education and Practice, 9(23), 108-119.

Sariyasa. (2017). Creating dynamic learning environment to enhance students' engagement in 
learning geometry creating dynamic learning environment to enhance students' engagement in learning geometry. Journal of Physics: Conference Series, 755(1), 011001. https://doi.org/10.1088/1742-6596/755/1/011001.

Sulistiowati, D. L., Herman, T., \& Jupri, A. (2019). Student difficulties in solving geometry problem based on Van Hiele thinking level. Journal of Physics: Conference Series, 1157(4), 042118. https://doi.org/10.1088/1742-6596/1157/4/042118.

Usiskin, Z. (1982). Van Hiele levels and achievement in secondary school geometry. CDASSG Project, 66, 37-39.

Usman, H., Yew, W. T., \& Saleh, S. (2019). Effects of Van Hiele's phase-based teaching strategy and gender on pre-service mathematics teachers' attitude towards geometry in Niger State, Nigeria. African Journal of Educational Studies in Mathematics and Sciences, 15(1), 61-75. https://doi.org/10.4314/ajesms.v15i1.6.

Vojkuvkova, I. (2012). The Van Hiele model of geometric thinking. WDS'12 Proceedings of Contributed Papers, 1, 72-75.

Yudianto, E., Sugiarti, T., \& Trapsilasiwi, D. (2018). The identification of Van Hiele level students on the topic of space analytic geometry. Journal of Physics: Conference Series 983(1), 012078. https://doi.org/10.1088/1742-6596/983/1/012078. 